\title{
Incidence and clinical significance of lactose malabsorption in ulcerative colitis and Crohn's disease ${ }^{1}$
}

\author{
E. GUDMAND-HØYER AND STIG JARNUM \\ From Rigshospitalet, Copenhagen
}

SUMMARY The incidence of lactose malabsorption was investigated in 85 patients with ulcerative colitis and 71 patients with Crohn's disease by means of lactose tolerance tests and $\overrightarrow{\vec{\varphi}}$ disaccharidase determinations in small intestinal mucosa. Eight patients with ulcerative colitis (9\%) and four with Crohn's disease $(6 \%)$ had lactose malabsorption. A control groupo displayed a similar incidence. It is concluded that lactose malabsorption is not particularly common in ulcerative colitis and Crohn's disease. If it is present, its aetiology seems to be unrelated to the intestinal disease.

Transitional lactose malabsorption was detected in two cases during a relapse of ulcerative colitis.

Institution of a lactose-free (or lactose-poor) diet was an important supporting measure in seven patients who were unaware of their milk intolerance, in particular in two with ileos-? tomy. Therefore, it is recommended that a lactose tolerance test should always be performed in patients with ulcerative colitis or Crohn's disease.

Twenty-one patients with ulcerative colitis and nine with Crohn's disease, none of whom: had lactose malabsorption, were placed on milk-free diets. A beneficial effect was noticed in five of the patients with ulcerative colitis, and in three of those with Crohn's disease. The ${ }_{0}$ mechanism is unknown.

Evidence is presented that milk allergy is not responsible for the beneficial effect of a lactose- $-\frac{T}{=}$ free diet in patients with associated lactose malabsorption.

In 1925 Andresen suggested that milk might be harmful to patients with ulcerative colitis, and in 1942 (Andresen, 1942) he reported that more than half of 50 patients with ulcerative colitis benefited from a milk-free diet. More recently, Truelove (1961) made a convincing demonstration to this effect in five patients. They all responded favourably to a milk-free regime and, more important, they suffered a relapse within days or weeks following the reintroduction of milk in their diet.

Lactose malabsorption is a frequent cause of chronic or intermittent diarrhoea and other abdominal complaints (Dahlqvist, Hammond; Crane, Dunphy, and Littman, 1963; Auricchio ${ }^{\circ}$ Rubino, Landolt, Semenza, and Prader, 1963) Therefore the beneficial effect of a milk-free $\frac{\mathrm{P}}{\mathrm{D}}$ diet in ulcerative colitis might be ascribed to associated lactose malabsorption. A surprisingle high incidence of lactose malabsorption (aboug $50 \%$ ) has been reported in both ulcerative colitis and regional enteritis (Littman, Cady, and5 Rhodes, 1968), but nonetheless the true incidence is still at dispute.

${ }^{1}$ This work was supported by grants from P. Carl Petersens Fond and Christian d. X's Fond. 


\begin{tabular}{llllll}
\hline & $\begin{array}{l}\text { Ulcerative } \\
\text { Colitis }\end{array}$ & \multicolumn{2}{l}{ Crohn's } & Disease & Total \\
\cline { 3 - 5 } & & $\begin{array}{l}\text { Small } \\
\text { Intestine }\end{array}$ & $\begin{array}{l}\text { Small } \\
\text { Intestine } \\
\text { and Colon }\end{array}$ & Colon \\
& & \multicolumn{4}{c}{${ }^{2}$} \\
\hline M & 38 & 7 & 16 & 4 & 27 \\
F & 47 & 13 & 26 & 5 & 44 \\
Total & 85 & 20 & 42 & 9 & 71 \\
$\begin{array}{llllll}\text { Number } \\
\text { operated }\end{array}$ & 44 & 15 & 31 & 7 & 53 \\
\hline
\end{tabular}

Table I Present series of 85 patients with ulcerative colitis and 71 patients with Crohn's disease

\begin{tabular}{|c|c|c|c|c|c|c|}
\hline & \multicolumn{3}{|l|}{ Ulcerative Colitis } & \multicolumn{3}{|c|}{ Crohn's Disease } \\
\hline & $\begin{array}{l}\text { Lactose Tolerance } \\
\text { Test }\end{array}$ & $\begin{array}{l}\text { Glucose- } \\
\text { galactose } \\
\text { Tolerance } \\
\text { Test }\end{array}$ & $\begin{array}{l}\text { Enzyme Activity } \\
\text { of Small-Intes- } \\
\text { tinal Mucosa }\end{array}$ & $\begin{array}{l}\text { Lactose } \\
\text { Tolerance } \\
\text { Test }\end{array}$ & $\begin{array}{l}\text { Glucose- } \\
\text { galactose } \\
\text { Tolerance } \\
\text { Test }\end{array}$ & $\begin{array}{l}\text { Enzyme Acti- } \\
\text { vity of Small } \\
\text { e Intestinal } \\
\text { Mucosa }\end{array}$ \\
\hline $\begin{array}{l}\mathbf{M} \\
\mathbf{F}\end{array}$ & $\begin{array}{l}38 \\
46\end{array}$ & $\begin{array}{l}13 \\
16\end{array}$ & $\begin{array}{l}11 \\
11\end{array}$ & $\begin{array}{l}25 \\
44\end{array}$ & $\begin{array}{r}7 \\
15\end{array}$ & $\begin{array}{l}18 \\
22\end{array}$ \\
\hline Total & 84 & 29 & 22 & 69 & 22 & 40 \\
\hline
\end{tabular}

Table II Investigations performed

\begin{tabular}{lcll}
\hline $\begin{array}{l}\text { Lactose } \\
\text { Malabsorption }\end{array}$ & $\begin{array}{l}\text { Ulcerative Colitis } \\
\text { (85 Patients) }\end{array}$ & $\begin{array}{l}\text { Crohn's Disease } \\
\text { (71 Patients) }\end{array}$ & $\begin{array}{l}\text { Total } \\
\text { (156 Patients) }\end{array}$ \\
\hline $\begin{array}{l}\text { With } \\
\text { Without }\end{array}$ & $87(9 \%)$ & $4(6 \%)$ & $12(8 \%)$ \\
\hline
\end{tabular}

Table III Incidence of lactose malabsorption

The present report deals with the incidence and clinical significance of lactose malabsorption in 156 patients with ulcerative colitis or regional enteritis.

\section{Case Material}

The case material was collected over a period of four years, 1965-1969 (Table I). Eighty-five patients with ulcerative colitis and 71 patients with Crohn's disease were studied.

The diagnosis of ulcerative colitis was based on a typical case history of visible blood in the stools and haemorrhagic discharge from the rectum, the proctosigmoidoscopic findings, and radiological examination of the colon. Crohn's disease was diagnosed in most cases by means of a small intestinal series and a barium enema in addition to a typical case history (diarrhoea, pain, recurrent subileus), laboratory data (benzidine-positive stools, elevated sedimentation rate, anaemia, hypoalbuminaemia, and frequent $B_{12}$ malabsorption).

The diagnosis was confirmed at laparotomy in 44 of 85 patients with ulcerative colitis and in 53 of 71 patients with Crohn's disease.

The age distribution was very similar in the two groups, which contained only two children (11 and 14 years old). The sex ratio, female/ male was $1: 1.2$ in patients with ulcerative colitis and $1: 1.6$ in patients with Crohn's disease.

\section{Methods}

The diagnosis of lactose malabsorption was established by means of a lactose tolerance test and/or determination of jejunal mucosal lactase activity.

\section{LACTOSE TOLERANCE TEST}

Blood glucose was determined regularly for two hours following the oral intake of $100 \mathrm{~g}$ lactose (Gudmand-Høyer and Jarnum, 1968). Clinical symptoms arising during the test were carefully registered.

In about one third of the patients (51) a control tolerance test was performed with a mixture of $50 \mathrm{~g}$ glucose and $50 \mathrm{~g}$ galactose.

\section{SMALL-INTESTINAL ENZYME ACTIVITY}

Mucosal biopsies were obtained at or up to $20 \mathrm{~cm}$ distal to Treitz's ligament by means of Rubin's hydraulic multibiopsy suction tube. Lactase, sucrase, and maltase activities were determined by means of Messer and Dahlqvist's one-step method (1966) and expressed as international units per gram protein. Protein was determined by Lowry's method, and alkaline phosphatase by the method of Bessey, Lowry, and Brock (1946)

Biopsies were obtained from 62 patients, 22 with ulcerative colitis and 40 with Crohn's disease (Table II).

The presence of lactose malabsorption was accepted if two of the following three criteria were fulfilled: (1) abnormally low rise of blood glucose (less than $25 \mathrm{mg} / 100 \mathrm{ml}$ ) during the lactose tolerance test as opposed to a normal rise during glucose-galactose tolerance test; (2) abdominal complaints (diarrhoea, borborygmia, bloating, flatulence) during the lactose tolerance test, but not after the control test with glucose and galactose; (3) decreased small intestinal mucosal lactase activity (ie, less than 9 iu per g protein).

\section{Results}

INCIDENCE OF LACTOSE MALABSORPTION Lactose malabsorption was present in eight patients with ulcerative colitis and in four with Crohn's disease (Table III), a relative incidence of $9 \%$ and $6 \%$, respectively. 


\begin{tabular}{|c|c|c|c|c|c|c|}
\hline \multirow[t]{2}{*}{ Case Number } & \multirow[t]{2}{*}{ Age (years) } & \multirow[t]{2}{*}{$\operatorname{Sex}$} & \multirow[t]{2}{*}{$\begin{array}{l}\text { Diagnosis, other than Lactose } \\
\text { Malabsorption }\end{array}$} & \multirow[t]{2}{*}{$\triangle B S-L T T^{1}$} & $\triangle B S-L T T$ & \multirow[t]{2}{*}{ Lactase } \\
\hline & & & & & $\triangle B S-G G T T^{1}$ & \\
\hline 1 & 49 & $\mathbf{M}$ & $\begin{array}{l}\text { Ulcerative colitis, total colectomy } \\
\text { with ileostomy }\end{array}$ & 14 & $0 \cdot 13$ & $2 \cdot 8$ \\
\hline 2 & 63 & $\mathbf{M}$ & Ulcerative colitis & 61 & & $2 \cdot 2$ \\
\hline 3 & 53 & $\mathbf{M}$ & $\begin{array}{l}\text { Ulcerative colitis, total colectomy } \\
\text { with ileostomy }\end{array}$ & 16 & $0 \cdot 15$ & $1 \cdot 4$ \\
\hline 4 & 14 & $\mathbf{M}$ & Ulcerative colitis & 12 & $0 \cdot 18$ & - \\
\hline 5 & 25 & $\mathbf{F}$ & $\begin{array}{l}\text { Ulcerative colitis, subtotal } \\
\text { colectomy with ileorectal } \\
\text { anastomosis }\end{array}$ & 11 & $0 \cdot 16$ & $1 \cdot 4$ \\
\hline 6 & 39 & $\mathbf{M}$ & Ulcerative colitis, ileostomy & 7 & $0 \cdot 10$ & 0 \\
\hline 7 & 24 & $\mathbf{F}$ & $\begin{array}{l}\text { Ulcerative colitis, total colectomy } \\
\text { with ileostomy }\end{array}$ & 12 & $0 \cdot 18$ & 0 \\
\hline 8 & 70 & $\mathbf{M}$ & Ulcerative colitis & 24 & - & - \\
\hline 9 & 43 & $\mathbf{F}$ & $\begin{array}{l}\text { Crohn's disease, } \\
\text { ileotransversostomy }\end{array}$ & 22 & $0 \cdot 26$ & $0 \cdot 3$ \\
\hline 10 & 55 & $\mathbf{F}$ & Crohn's disease & 12 & $0 \cdot 26$ & $0 \cdot 3$ \\
\hline 11 & 21 & $\mathbf{M}$ & Crohn's disease & 10 & $0 \cdot 11$ & $1 \cdot 8$ \\
\hline 12 & 25 & $\mathbf{F}$ & $\begin{array}{l}\text { Crohn's disease, ileocaecal } \\
\text { resection }\end{array}$ & 18 & $0 \cdot 29$ & - \\
\hline
\end{tabular}

Table IV Blood sugar rise during sugar tolerance tests, and mucosal lactase activity in patients with lactose malabsorption

${ }^{1} \mathrm{BS}=$ maximum blood sugar rise $(\mathrm{mg} / 100 \mathrm{ml})$ during sugar tolerance test, LTT =lactose tolerance test, and GGTT=glucosegalactose tolerance test.

\begin{tabular}{|c|c|c|c|c|c|}
\hline Case Number & $\begin{array}{l}\text { Duration of Disease } \\
\text { (years) }\end{array}$ & $\begin{array}{l}\text { Milk Intolerance } \\
\text { before Intestinal } \\
\text { Disease }\end{array}$ & $\begin{array}{l}\text { Milk Consumption } \\
\text { before Detection of } \\
\text { Lactose Malabsorption }\end{array}$ & $\begin{array}{l}\text { Effect of } \\
\text { Lactose-free Diet }\end{array}$ & Ileostomy \\
\hline 1 & 4 & No & 2-3 glasses/week & + & + \\
\hline 2 & $1 / 4$ & $?$ & + & Died before trial & \\
\hline 3 & 14 & No & 1-2 glasses/day & + & + \\
\hline 4 & $\frac{1}{2}$ & No & + & + & \\
\hline 5 & 2 & No & 2-3 glasses/day & + & Ileorectostomy \\
\hline 6 & 7 & $?$ & 0 & & + \\
\hline 7 & 1 & $?$ & 0 & & + \\
\hline 8 & 19 & $?$ & 0 & & \\
\hline 9 & 25 & No & 3 glasses/day & + & Ileotransversostomy \\
\hline 10 & $?$ & No & 1-2 glasses/day & + & \\
\hline 11 & 2 & No & 2 glasses/day & + & \\
\hline 12 & 8 & $?$ & 0 & & \\
\hline
\end{tabular}

Table V Clinical significance of lactose malabsorption

PATIENTS WITH LACTOSE MALABSORPTION The data on these patients are presented in Table IV. Eleven patients had a flat blood sugar curve during lactose tolerance testing. One patient (case 2) showed a steady rise up to $61 \mathrm{mg} / 100 \mathrm{ml}$ after two hours, but he had diabetes, and, like the other patients, developed abdominal symptoms during the test. His small intestinal lactase activity was definitely lowered $(2 \cdot 2 \mathrm{iu} / \mathrm{g}$ protein).

A glucose-galactose tolerance test was performed in 10 cases (the remaining two, cases 2 and 8 , died before it could be done). The test was normal in everyone and unassociated with abdominal distress. Mucosal lactase activity was depressed in all nine patients examined. Sucrase, maltase, and alkaline phosphatase were normal. Stereomicroscopy showed normal villi in all biopsies. Routine microscopic examination revealed slight chronic inflammation in two patients with ulcerative colitis. It was normal in the remaining seven patients.

\section{CLINICAL SIGNIFICANCE OF ASSOCIATED} LACTOSE MALABSORPTION

None of the patients with lactose malabsorption had noticed milk intolerance before the in- ? testinal disease. Four patients never drank milk, two (cases 6 and 8) did not drink milk at the time of the investigation, because they were milk intolerant, and two because they disliked the $\varrho$ taste (Table V). Eight patients drank milk until lactose malabsorption was demonstrated.

In seven milk drinkers lactose malabsorption caused or contributed to chronic diarrhoea in all of them, since a lactose-free diet resulted in a 를 considerable reduction, and in four (cases 4, 9, 10, and 11) even total cessation of diarrhoea. In two patients with ileostomy (cases 1 and 3) 


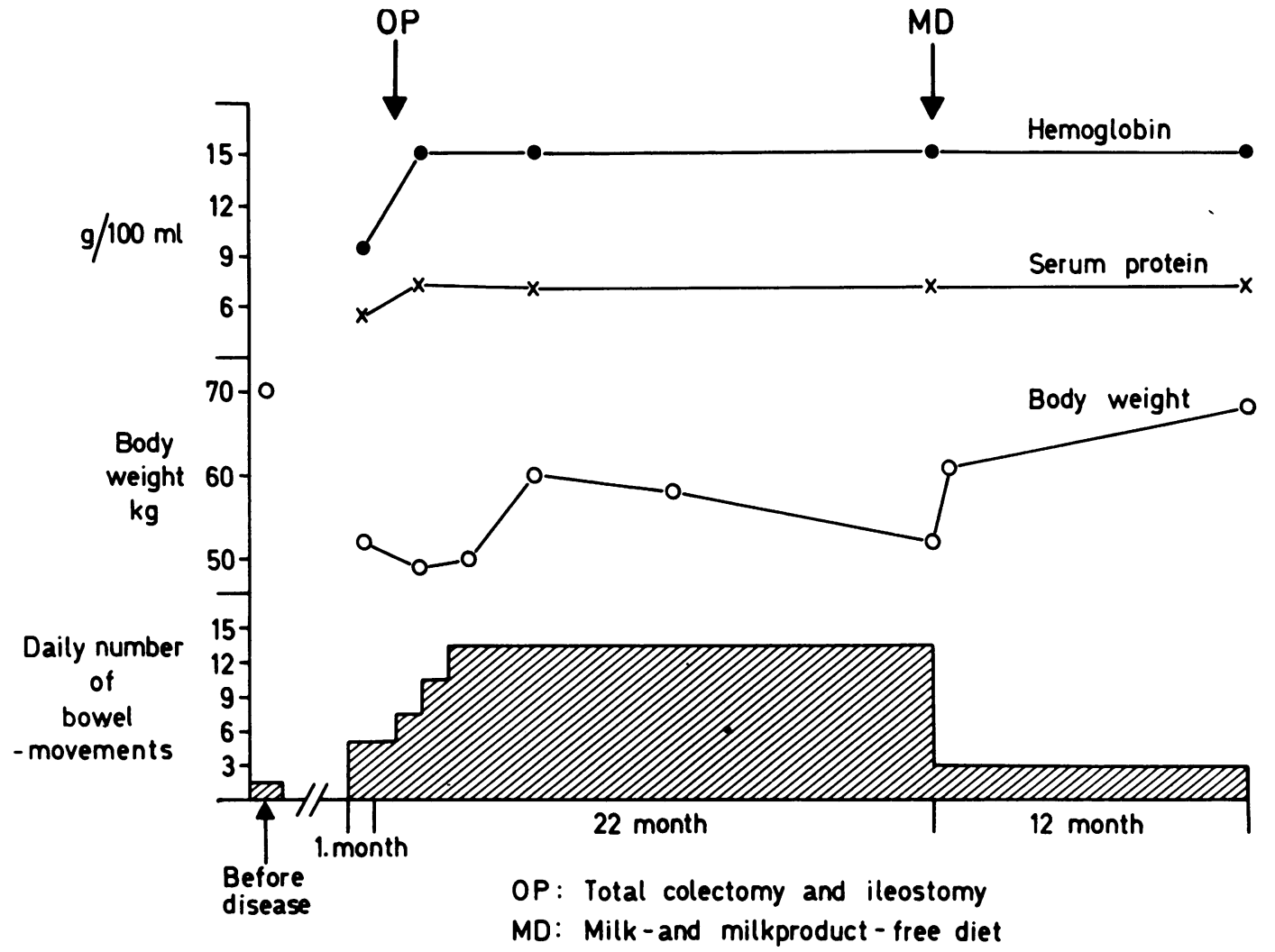

Fig. Effect of a lactose-free diet on the number of daily bowel movements and body weight in an ileostomy patient (case 3) with lactose malabsorption.

\begin{tabular}{|c|c|c|c|c|c|c|c|c|c|}
\hline \multirow[t]{2}{*}{ Authors } & \multirow[t]{2}{*}{ Country } & \multicolumn{2}{|c|}{ Ulcerative Colitis } & \multicolumn{2}{|c|}{ Crohn's Disease } & \multicolumn{2}{|l|}{ Controls } & \multicolumn{2}{|c|}{ Diagnosis Based on } \\
\hline & & $\begin{array}{l}\text { Number } \\
\text { of Patients } \\
\text { Studied }\end{array}$ & $\begin{array}{l}+ \\
\text { Lactose } \\
\text { Malabsorption }\end{array}$ & $\begin{array}{l}\text { Number } \\
\text { of Patients } \\
\text { Studied }\end{array}$ & $\begin{array}{l}+ \\
\text { Lactose } \\
\text { Malabsorption }\end{array}$ & $\begin{array}{l}\text { Number } \\
\text { of Patients } \\
\text { Studied }\end{array}$ & $\begin{array}{l}+ \\
\text { Lactose } \\
\text { Malabsorption }\end{array}$ & $\begin{array}{l}\text { Lactose } \\
\text { Tolerance } \\
\text { Test }\end{array}$ & $\begin{array}{l}\text { Determination of } \\
\text { Mucosal Enzyme } \\
\text { Activity }\end{array}$ \\
\hline $\begin{array}{l}\text { Cady et al (1967) } \\
\text { Littman et al (1968) } \\
\text { Binder } \text { et al (1966) } \\
\text { Newcomer and McGill (1967) } \\
\text { Chalfin and Holt (1967) } \\
\text { Kojecký and Matlocha (1968) }\end{array}$ & $\begin{array}{l}\text { USA } \\
\text { USA } \\
\text { USA } \\
\text { USA } \\
\text { Czecho- } \\
\text { slovakia }\end{array}$ & $\begin{array}{r}29 \\
39 \\
24 \\
9 \\
18\end{array}$ & $\begin{array}{l}13(45 \%) \\
19(49 \%) \\
2(8 \%) \\
4(44 \%) \\
9(50 \%)\end{array}$ & 11 & $\begin{array}{l}5(45 \%) \\
3(60 \%)\end{array}$ & $\begin{array}{r}93 \\
37 \\
100\end{array}$ & $\begin{array}{l}18(19 \%) \\
18(49 \%) \\
6(6 \%)\end{array}$ & $\begin{array}{l}+ \\
+ \\
+ \\
+ \\
+\end{array}$ & $\begin{array}{l}+ \\
+ \\
+\end{array}$ \\
\hline $\begin{array}{l}\text { Montgomery, Frazer, Hood, } \\
\text { Goodhart, Holland, and } \\
\text { Schnieder (1968) } \\
\text { Present invesigation and } \\
\text { Gudmand-Høyer Dahlqvist and } \\
\text { Jarnum (1969) }\end{array}$ & Denmark & 11 & $2(18 \%)$ & 71 & $4(6 \%)$ & 700 & $3-7 \%$ & + & + \\
\hline
\end{tabular}

Table VI Reports on the incidence of lactose malabsorption

the volume of ileostomy excreta decreased, and a distressing skin maceration around the ileostomy vanished.

One patient (case 3, Fig.), a farmer, had 10 to 20 watery movements a day. He applied for a disablement annuity because of extreme fatigue. Following the institution of a lactose-free diet his stools became normal within two days. In two weeks he gained $7 \mathrm{~kg}$ in weight and insisted on his discharge bezause he had to go home to sow his fields.

A third patient with ileostomy (case 6) noticed milk intolerance immediately after the operation and has avoided milk ever since.

Case 5 with an ileorectostomy had up to two bowel movements a day. Her general condition deteriorated and she suffered a severe weight loss. Salicylazosulphapyridine, prednisone, and a 
low-fat diet were unbeneficial. Following the detection of lactose malabsorption and a lactosefree diet she made a speedy recovery, gained weight, and had no complaints at a five-month check-up.

\section{Discussion}

INCIDENCE OF LACTOSE MALABSORPTION A well-nigh $50 \%$ incidence of lactose malabsorption in ulcerative colitis (Table) VI has been reported by several groups of workers (Cady, Rhodes, Littman, and Crane, 1967; Binder, Gryboski, Thayer, and Spiro, 1966; Kojecký and Matlocha, 1968). In contrast, Newcomer and McGill (1967b) in their series of 24 patients found a low incidence equal to that of a control group (Newcomer and McGill, 1967a). In the present series the incidence was also low, although twice as high as in our control material (GudmandHøyer, Dahlqvist, and Jarnum, 1969). However, the difference was statistically insignificant $(P>$ $0 \cdot 10)$. In view of the fact that our series comprised 85 patients with ulcerative colitis, a larger group than any of the series listed above, we conclude that lactose malabsorption is not particularly common in ulcerative colitis.

Morphological alterations of the small-intestinal mucosa have been detected in patients with ulcerative colitis (Salem, Truelove, and Richards, 1964) and, in particular, in an active phase of the disease (Salem and Truelove, 1965). These alterations may result in a decreased disaccharidase content of the small-intestinal epithelium. A low content of several disaccharidases has actually been reported in ulcerative colitis (Kojecký and Matlocha, 1968). Being the most 'sensitive' enzyme, lactase might be more depressed than other disaccharidases. Cady et al (1967) were unable to detect small intestinal lactase activity (at Treitz's ligament) in three severely ill patients with ulcerative colitis. The disaccharidase level became low normal following remission. However, Cady and his co-workers did not find lactose malabsorption to be significantly more frequent in acute stages of ulcerative colitis.

In the present report eight patients with ulcerative colitis had lactose malabsorption. Seven were, or had just been, in an acute or active phase, since they were operated on very soon after, or just before, the investigation. It was remarkable that none of them had observed milk intolerance before the onset of colitis. In an additional two patients the lactose tolerance test and the presence of milk intolerance indicated lactose malabsorption during an acute stage, but, following successful medical treatment, the lactose tolerance test became normal and the patients resumed drinking milk without discomfort. Therefore, it seems likely that lactose malabsorption may be present as a transitional phenomenon during an active phase of the disease.

In Crohn's disease we found the incidence of lactose malabsorption to be of the same order of $\Omega$ magnitude as in a control group. The coexistence of the two diseases in the same individual appears $\overline{\bar{s}}$ to be fortuitous.

CLINICAL SIGNIFICANCE OF LACTOSE

MALABSORPTION

Chronic or intermittent diarrhoea is a symptom कै common to ulcerative colitis, Crohn's disease,. and lactose malabsorption. Since specific lactose $\overrightarrow{\vec{\omega}}$ malabsorption is present in about $5 \%$ of the $\stackrel{\omega}{\mathscr{L}}$ population in western countries a fortuitous association between lactose malabsorption and ulcerative colitis or Crohn's disease cannot be rare. Therefore, every patient with one of these $\dot{\omega}$ two inflammatory conditions should be tested $\mathscr{\omega}_{\infty}$ for lactose malabsorption.

A marked improvement during lactose-free diet in ulcerative colitis associated with lactose $\rightarrow$ malabsorption has been reported by Cady et al (1967) and Binder et al (1966).

The present series contains several similar $\vec{\partial}$ examples. One patient (case 9, Table V) had chronic diarrhoea following ileotransversostomy for Crohn's disease 20 years earlier. When lactose malabsorption was detected, she was placed on a lactose-free diet and diarrhoea $\frac{\varnothing}{\varnothing}$ ceased. In another four patients (cases $4,9,10, \stackrel{\varrho}{\Rightarrow}$ and 11) a lactose-free diet was an important supporting part of the treatment.

Colectomized patients present special problems. In our series three patients with ulcerative colitis suffered severe, chronic diarrhoea following $\stackrel{\varrho}{=}$ colectomy with ileostomy (cases 1 and 3) or ileo- $\frac{\dot{0}}{\overrightarrow{0}}$ rectostomy (case no. 5). The ileostomy patients had skin emaceration around the stoma. Both $ᄋ$ the diarrhoea and the skin emaceration disappeared when the presence of lactose malabsorption $\frac{9}{5}$ was established and they were put on a lactose- $\rightarrow$ free diet.

Altogether, in seven patients with ulcerative N colitis or Crohn's disease, the demonstration of lactose malabsorption and institution of a $\widetilde{N}$ lactose-free diet significantly contributed to, or $\underset{\omega}{ }$ caused, a clinical remission. In four other patients

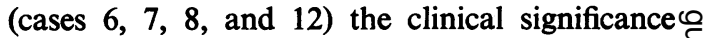
of associated lactose malabsorption was less $\stackrel{\mathscr{D}}{\mathscr{D}}$ evident since they had always avoided milk. + It is indirect evidence that the lactose mal- $\frac{T}{0}$ absorption existed long before they contracted $\frac{\mathrm{O}}{\mathrm{D}}$ the intestinal disease, and that the two con- $\varrho$ ditions were unrelated.

MILK ALLERGY AND LACTOSE

MALABSORPTION

Wright and Truelove (1965) reported that about one fifth of their patients with ulcerative colitis benefited from a milk-free diet. Their series was not tested for lactose malabsorption. Since one 
fifth is more than the number expected to suffer from lactose malabsorption, the question arises whether some of them suffered from milk allergy. We made a similar trial and placed 21 patients with ulcerative colitis and nine patients with Crohn's disease on a milk-free diet. None of them had lactose malabsorption. Nevertheless, the diet was beneficial in five patients with ulcerative colitis and in three with Crohn's disease, as judged from the numbers of movements and their feeling of well being. Thus we can add some support to Truelove's recommendation of a trial of milk-free diet. Whether the effect is due to milk allergy remains unknown. Antibodies against milk protein are not particularly common in ulcerative colitis (Sewell, Cooke, Cox, and Meynell, 1963).

When patients with lactose malabsorption benefit from a lactose-free diet, it might partly be due to a simultaneous 'milk allergy'. Although we were unable to exclude this mechanism in our series, it was remarkable that two patients (cases 10 and 11) with lactose malabsorption improved markedly on a lactose-free regime which included a supplement of a lactose-free milk preparation containing milk proteins and milk fat ${ }^{1}$. Furthermore, in case 10 the addition of lactose to a milk-free diet produced the same symptoms (severe diarrhoea, abdominal pains) as a milk-containing diet. Therefore, the symptoms evoked by milk in patients with complicating lactose malabsorption are probably due to lactose only.

${ }^{1}$ Lida-Lac LIDANO, 4400 Kalundborg, Denmark.

\section{References}

Andresen, A. F. R. (1925). Gastrointestinal manifestations of food allergy. Med.J. Rec., 122, 271-275.

Andresen, A. F. R. (1942). Ulcerative colitis: an allergic phenomenon. Amer.J.dig. Dis., 9,91-98.

Auricchio, S., Rubino, A., Landolt, M., Semenza, G., and Prader, A. (1963). Isolated intestinal lactase deficiency in the adult. Lancet, 2, 324-326.

Bessey, O. A., Lowry, O. H., and Brock, M. J. (1946). A method for the rapid determination of alkaline phosphatase with five cubic millimeters of serum. J. biol. Chem., 164, 321-329.
Binder, H. J., Gryboski, J. D., Thayer, W. R., Jr., and Spiro, H. M. (1966). Intolerance to milk in ulcerative colitis. Amer. J. dig. Dis., n.s., 11, 858-864.

Cady, A. B., Rhodes, J. B., Littman, A., and Crane, R. K. (1967) Significance of lactase deficit in ulcerative colitis. J. Lab. clin. Med., 70, 279-286.

Chalfin, D., and Holt, P. R. (1967). Lactase deficiency in ulcerative colitis, regional enteritis, and viral hepatitis. Amer. $J$. dig. Dis., n.s., 12, 81-87.

Dahlqvist, A., Hammond, J. B., Crane, R. K., Dunphy, J. V., and Littman, A. (1963). Intestinal lactase deficiency and lactose intolerance in adults: preliminary report. Gastroenterology, 45, 488-491.

Gudmand-Høyer, E., Dahlqvist, A., and Jarnum, S. (1969). Specific small-intestinal lactase deficiency in adults. Scand. J. Gastroent., 4, 377-386.

Gudmand-Høyer, E., and Jarnum, S. (1968). The diagnosis of lactose malabsorption. Scand. J. Gastroent., 3, 129-139.

Kojecký, Z., and Matlocha, Z. (1968). Comparative studies on intestinal dissaccharidase activities, isoenzymes of lactic acid, malic acid dehydrogenases, alkaline phosphatase and unspecific esterase in ulcerative colitis. Amer. $J$. Proctol., 19, 204-209.

Littman, A., Cady, A. B., and Rhodes, J. (1968). Lactase and other disaccharidase deficiencies in a hospital population. Israel J. med. Sci., 4, 110-116.

Messer, M., and Dahlqvist, A. (1966). A one-step ultramicro method for the assay of intestinal disaccharidases. Analyt. Biochem., 14, 376-392.

Montgomery, R. D., Frazer, A. C., Hood, C., Goodhart, J. M., Holland, M. R., and Schneider, R. (1968). Studies of intestinal fermentation in ulcerative colitis. Gut, 9, 521-526.

Newcomer, A. D., and McGill, D. B. (1967a). Disaccharidase activity in the small intestine: prevalence of lactase deficiency in 100 healthy subjects. Gastroenterology, 53, 881-889.

Newcomer, A. D., and McGill, D. B. (1967b). Incidence of lactase deficiency in ulcerative colitis. Gastroenterology, 53, 890-893.

Salem, S. N., and Truelove, S. C. (1965). Small-intestinal and gastric abnormalities in ulcerative colitis. Brit. med. J., $1,827-831$.

Salem, S. N., Truelove, S. C., and Richards, W. C. D. (1964). Small-intestinal and gastric changes in ulcerative colitis: a biopsy study. Brit. med. J., 1, 394-398.

Sewell, P., Cooke, W. T., Cox, E. V., and Meynell, M. J. (1963). Milk intolerance in gastrointestinal disorders. Lancet. 2 , 1132-1135.

Truelove, S. C. (1961). Ulcerative colitis provoked by milk. Brit. med.J., 1, 154-160.

Wright, R., and Truelove, S. C. (1965). A controlled therapeutic, trial of various diets in ulcerative colitis. Brit. med. J., 2 138-141. 